\title{
Constituents of Stem Bark of Callistemon rigidus Showing Inhibitory Effects on Mouse $\alpha$-Amylase Activity
}

\author{
Kyoko Kobayashi, ${ }^{a}$ Tamaki Ishinara, ${ }^{a}$ Eriko Khono,${ }^{b}$ Toshio Miyase, ${ }^{b}$ and Fumihiko Yoshizaki ${ }^{*}, a$ \\ ${ }^{a}$ Tohoku Pharmaceutical University; 4-4-1 Komatsushima, Aoba-ku, Sendai 981-8558, Japan: and ${ }^{b}$ University of \\ Shizuoka; 52-1 Yata, Suruga-ku, Shizuoka 422-8526, Japan. Received December 5, 2005; accepted February 7, 2006
}

From stem bark of Callistemon rigidus (Myrtaceae), piceatannol and scirpusin B were isolated as components that exhibit inhibitory effects on $\alpha$-amylase activity in isolated mouse plasma. In particular, scirpusin B also inhibited $\alpha$-amylase in mouse gastrointestinal tract. Thus, we expect the depressive effect on the elevation of postprandial blood glucose may be a new medicinal use of this compound as well as the plant itself.

Key words scirpusin B; $\alpha$-amylase; blood plasma; blood glucose; mouse

It is well known that the incidence of diabetes mellitus caused as lifestyle disease is increasing and has become something of a social problem in recent years. $\alpha$-Glucosidase inhibitors, medicines that prevent elevation of postprandial blood glucose, can control blood glucose levels without depending on increased secretion of insulin and results in lowering the amount of insulin required after meals. A similar effect to that of these medicines can be expected as a result of $\alpha$-amylase inhibition.

Although the influential factor seems to be an inconsistency in the source of enzyme, we have called attention to $\alpha$ amylase in plasma and gastrointestinal tube of mouse and have surveyed crude drugs and plants that elicit inhibitory activity on this enzyme for the purpose of finding new uses of these materials. ${ }^{1,2)}$ In this study, we found that stem bark of Callistemon rigidus (Myrtaceae) intensely inhibits $\alpha$-amylase activity in isolated mouse plasma in vitro. Consequently, we investigated the active components in this plant and examined the inhibitory effects of these isolated components on $\alpha$-amylase in mouse gastrointestinal tract in vivo.

\section{MATERIALS AND METHODS}

Materials Stems of Callistemon rigidus were obtained from plants in the medicinal plant garden at the University of Shizuoka. Glycogen was purchased from Nacalai Tesque (Tokyo) and acarbose was obtained from Bayer Pharmaceuticals (Osaka).

Extraction and Isolation Optical rotation was determined by JASCO DIP-1000 polarimeter. Perkin-Elmer FT-IR $1725 \mathrm{X}$ was used for measurement of IR spectra. Mass spectra (EI-MS) were taken on a JEOL JMS-DX 303 mass spectrometer. ${ }^{1} \mathrm{H}$ - and ${ }^{13} \mathrm{C}-\mathrm{NMR}$ spectra were recorded with a JEOL alpha 400 spectrometer $(400,100 \mathrm{MHz})$ and chemical shifts are given in $\delta(\mathrm{ppm})$ with tetramethylsilane as internal standard $(\mathrm{s}=$ singlet, $\mathrm{d}=$ doublet, $\mathrm{dd}=$ double doublet, $\mathrm{t}=$ triplet). R-355-15-ODS ( $50 \mathrm{~mm}$ i.d. $\times 50 \mathrm{~cm}$, YMC Co., Ltd.) $\times 2$ was employed as the column for preparative HPLC. The mobile phase was $20 \%$ acetonitrile $\rightarrow 25 \%$ acetonitrile $(9 \mathrm{~h}$, detected at $205 \mathrm{~nm}$, room temperature) and the flow rate was $45 \mathrm{ml} / \mathrm{min}$.

Stems were refluxed (for $1 \mathrm{~h}$ ) three times with a five-fold volume of methanol and filtered, followed by removal of the combined solvent in vacuo. The extract was completely dried in vacuo. The residue was dissolved in water and succes- sively partitioned between chloroform, ethyl acetate, and $n$ butanol three times each. After removal of the respective solvents, individual extracts were obtained. The yield of each extract is displayed in Table 1. Ethyl acetate extract was column chromatographed on silica gel (PSQ-100B, Fuji silysia) guided by inhibitory activity using chloroform-methanol as eluent to give compound $\mathbf{1}$ (yield, $2.30 \mathrm{mg} / \mathrm{g}$ of stem). Further purification of the fractions showing considerable activity by preparative HPLC gave compound $2\left(t_{\mathrm{R}}, 5.5 \mathrm{~h}\right.$; yield, $0.91 \mathrm{mg} / \mathrm{g}$ of stem).

1 (Piceatannol): A colorless amorphous powder; MS (EI) $m / z: 244\left(\mathrm{M}^{+}\right)$. IR (KBr): 966, 1142, 1296, 1347, 1445, $1521,1601,3296,3346,3513 \mathrm{~cm}^{-1} \cdot{ }^{1} \mathrm{H}-\mathrm{NMR}\left(\mathrm{CD}_{3} \mathrm{OD}\right) \delta$ : $6.23(1 \mathrm{H}, \mathrm{t}, J=2.0 \mathrm{~Hz}), 6.50(2 \mathrm{H}, \mathrm{d}, J=2.0 \mathrm{~Hz}), 6.78(1 \mathrm{H}, \mathrm{d}$, $J=7.5 \mathrm{~Hz}), 6.78(1 \mathrm{H}, \mathrm{d}, J=14.5 \mathrm{~Hz}), 6.86(1 \mathrm{H}, \mathrm{dd}, J=2.0$, $7.5 \mathrm{~Hz}), 6.92(1 \mathrm{H}, \mathrm{d}, J=14.5 \mathrm{~Hz}), 7.02(1 \mathrm{H}, \mathrm{d}, J=2.0 \mathrm{~Hz})$. ${ }^{13} \mathrm{C}-\mathrm{NMR}\left(\mathrm{CD}_{3} \mathrm{OD}\right) \delta$ : 102.6, 105.8×2, 113.8, 116.4, 120.2, $127.0,129.7,131.1,141.3,146.5 \times 2,159.6 \times 2$.

2 (Scirpusin B): A dark brownish amorphous powder; $[\alpha]_{\mathrm{D}}^{23} 0.0^{\circ}(c=1.0, \mathrm{MeOH}) . \mathrm{MS}(\mathrm{EI}) m / z: 486\left(\mathrm{M}^{+}\right)$. IR $(\mathrm{KBr}): 1002,1116,1156,1197,1282,1342,1446,1520$, 1603, $3307 \mathrm{~cm}^{-1}$. ${ }^{1} \mathrm{H}-\mathrm{NMR} \quad\left(\mathrm{CD}_{3} \mathrm{OD}\right) \delta: 4.38(1 \mathrm{H}, \mathrm{d}$, $J=6.0 \mathrm{~Hz}), 5.32(1 \mathrm{H}, \mathrm{d}, J=6.0 \mathrm{~Hz}), 6.19(2 \mathrm{H}, \mathrm{d}, J=2.0 \mathrm{~Hz})$, $6.21(1 \mathrm{H}, \mathrm{t}, J=2.0 \mathrm{~Hz}), 6.29(1 \mathrm{H}, \mathrm{d}, J=2.0), 6.57(1 \mathrm{H}, \mathrm{d}$, $J=16.5 \mathrm{~Hz}), 6.60(1 \mathrm{H}, \mathrm{dd}, J=2.0,8.0 \mathrm{~Hz}), 6.65(1 \mathrm{H}, \mathrm{d}$, $J=2.0 \mathrm{~Hz}), 6.67(1 \mathrm{H}, \mathrm{d}, J=8.0 \mathrm{~Hz}), 6.67(1 \mathrm{H}, \mathrm{dd}, J=2.0$, $8.0 \mathrm{~Hz}), 6.73(1 \mathrm{H}, \mathrm{d}, J=2.0 \mathrm{~Hz}), 6.77(1 \mathrm{H}, \mathrm{d}, J=8.0 \mathrm{~Hz}), 6.78$ $(1 \mathrm{H}, \mathrm{d}, J=16.5 \mathrm{~Hz}), 6.79(1 \mathrm{H}, \mathrm{d}, J=2.0 \mathrm{~Hz}) .{ }^{13} \mathrm{C}-\mathrm{NMR}$ (CD 3 OD) $\delta: 58.0,94.8,96.8,102.3,104.5,107.4 \times 2,113.7$, $114.0,116.3 \times 2,118.5,119.8,120.0,123.7,130.9,131.0$, $134.9,137.0,146.2,146.3,146.4,146.5,147.6,159.8 \times 3$, 162.7 .

Animals Five- to 6-week-old male mice of the ddY strain were purchased from Nihon SLC, Hamamatsu, Japan. They were housed in plastic cages with free access to food (until $24 \mathrm{~h}$ before use) and water, and were kept in a room at $25 \pm 1{ }^{\circ} \mathrm{C}, 55 \pm 5 \%$ humidity with a 12 -h dark-light cycle.

Assay of $\alpha$-Amylase Activity Amylase activity was measured according to the Caraway method ${ }^{3)}$ using a kit (Amylase-Test Wako, Wako Pure Chemical, Osaka), as described previously. ${ }^{1)}$ Cardiac blood was collected from the mice by heparin-treated cylinder and centrifuged to prepare the plasma. The plasma was diluted in isotonic sodium chloride solution to one-third and a $0.1 \mathrm{ml}$ portion of each test sample adjusted to each final reaction concentration in dis- 
tilled water was added to the mouse plasma for assay. Inhibitory activity $(\%)$ was calculated as $(1-B / A) \times 100$, where $A$ is the activity of the enzyme without test solution and $B$ the activity of the enzyme with test solution.

Estimation of Blood Sugar The assay was performed according to the $O$-toluidine-boric acid method ${ }^{4)}$ using a kit (Glucose-Test Wako, Wako Pure Chemical, Osaka) as mentioned previously. ${ }^{1)}$ Administration of samples and arrangement of plasma were also conducted as described previously. ${ }^{1)}$ Each test solution was given orally to the mice at a constant injection volume of $0.3 \mathrm{ml} / 30 \mathrm{~g}$ body weight.

Statistics Statistical analyses were carried out using Student's $t$-test. Values with $p<0.05$ were regarded as significant.

\section{RESULTS AND DISCUSSION}

Callistemon rigidus, with its origin in Australia, is one of the indeciduous arbores classified in Myrtaceae. Monoterpenoids and sesquiterpenoids have been identified as ingredients of the essential oil in the leaves, ${ }^{5,6)}$ seeds, ${ }^{6)}$ and fruits. ${ }^{7)}$ Flavonoids $^{8)}$ and triterpenoids ${ }^{9)}$ have also been reported to be constituents of the leaves.

Methanolic extract of the stem bark of Callistemon rigidus showed inhibitory activity of about $83 \%$ on isolated mouse blood plasma $\alpha$-amylase at a final concentration of 300 $\mu \mathrm{g} / \mathrm{ml}$ in the reaction solution. Acarbose, a $\alpha$-glucosidase inhibitor, was utilized as positive control (final concentration in reaction solution, $50 \mu \mathrm{g} / \mathrm{ml}$ ). This inhibitory action of methanolic extract was concentration-dependent and the $\mathrm{IC}_{50}$ was $81.1 \mu \mathrm{g} / \mathrm{ml}$.

The methanolic extract was dissolved in water and successively distributed between chloroform, ethyl acetate, and $n$ butanol to prepare the respective extracts. Ethyl acetate and $n$-butanol extracts showed intense inhibition of $\alpha$-amylase by about $45.8 \%$ and $51.1 \%$, respectively, while the chloroform extract exhibited no action. The final concentration of each extract in the reaction solution was calculated as $300 \times$ (yield of each extract/yield of methanolic extract) $\mu \mathrm{g} / \mathrm{ml}$. All of the results described above coupled with the yields of extracts are revealed in Table 1.

Furthermore, ethyl acetate extract was fractionated with the guidance of inhibitory activity on $\alpha$-amylase using silica gel column chromatography and preparative HPLC to isolate two compounds, $\mathbf{1}$ and $\mathbf{2}$. Compound $\mathbf{1}$, obtained as colorless amorphous powder, was identified as piceatannol, one of the stilbenes widespread in plants, such as Picea sp., ${ }^{10)}$ grapes, ${ }^{11)}$ rhubarb $^{12}$ and others, based on the various spectral data. Compound 2, isolated as a dark brownish amorphous powder, was concluded to be scirpusin B, a constituent of Scirpus fluviatilis, based on comparison of the various spectral data with those in the literature. ${ }^{13,14)}$ Since nuclear Overhauser effects were observed between each dihydrofuran ring proton $(\delta 4.38,5.32)$ and ortho position protons $(\delta 6.19,6.67,6.79)$ on both benzene rings joined with the dihydrofuran ring carbons bearing each dihydrofuran ring proton, 2 was speculated to be trans-type scirpusin B. Moreover, 2 was presumed to be racemate $\left([\alpha]_{\mathrm{D}} 0.0^{\circ}\right)$. This is the first time that these compounds have been found in Callistemon rigidus (Fig. 1). The inhibitory actions of both constituents were concentration-dependent and the $\mathrm{IC}_{50} \mathrm{~s}$ of $\mathbf{1}$ and $\mathbf{2}$ were 457.0 and
Table 1. Inhibitory Activities of Extracts from Callistemon rigidus on $\alpha$ Amylase in Mouse Plasma

\begin{tabular}{lccc}
\hline \hline Extract & $\begin{array}{r}\text { Yield } \\
(\mathrm{mg} / \mathrm{g})\end{array}$ & $\begin{array}{c}\text { Concentration }^{a)} \\
(\mu \mathrm{g} / \mathrm{ml})\end{array}$ & $\begin{array}{c}\text { Inhibition } \\
(\%)\end{array}$ \\
\hline Methanol & 29.0 & 300 & 82.9 \\
Chloroform & 9.0 & 93.1 & 8.5 \\
Ethyl acetate & 7.2 & 74.5 & 45.8 \\
$n$-Butanol & 4.6 & 47.6 & 51.1 \\
Water & 6.8 & 70.3 & 40.2 \\
Acarbose & & 50.0 & 63.1 \\
\hline
\end{tabular}

a) Concentration of test sample in reaction solution was calculated as $300 \times$ (yield of each extract/yield of methanol extract) $\mu \mathrm{g} / \mathrm{ml}$.
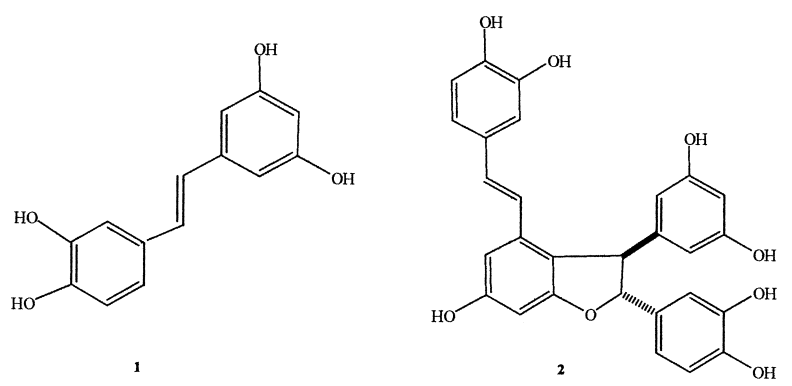

Fig. 1. Structures of $\mathbf{1}$ and $\mathbf{2}$

$90.5 \mu \mathrm{M}$, respectively, which are mild compared with acarbose, at $45.4 \mu \mathrm{M}$. Some constituents of plants that exhibit inhibitory effects on $\alpha$-amylase activities have recently been reported. ${ }^{15-17)}$ Here, piceatannol (1) and scirpusin B (2) have been newly applied. It is known that $\mathbf{1}$ inhibits various enzyme activities. ${ }^{18.19)} \mathbf{2}$ is also known as a xanthine oxidase inhibitor. $^{20)}$ Other $\alpha$-amylase inhibitors are expected to be found in $n$-butanol extract of stem bark of this plant.

Compounds 1 and 2, which exhibited influence on $\alpha$-amylase in isolated blood plasma in vitro, have the potential to inhibit this activity in mouse gastrointestinal tract. Therefore we successively evaluated the depressive effect of these components on rise of blood glucose level in glycogen-loaded mice. As a result, no variation of blood glucose level $30 \mathrm{~min}$ after oral administration of $1(400 \mathrm{mg} / \mathrm{kg})$ followed by administration of glycogen $(1500 \mathrm{mg} / \mathrm{kg})$ was observed. In contrast, 2 at a dose of $400 \mathrm{mg} / \mathrm{kg}$ significantly repressed increase of blood glucose $30 \mathrm{~min}$ after oral administration of glycogen $(1500 \mathrm{mg} / \mathrm{kg})$ by about $21.6 \%$, an extent of about half that of the depression caused by acarbose (positive control, $400 \mathrm{mg} / \mathrm{kg}$, p.o.). Moreover, change of glucose concentration in glycogen-loaded mouse plasma after oral administration of scirpusin B was investigated. As shown in Fig. 2, blood glucose level reached maximum at $30 \mathrm{~min}$ and gradually decreased thereafter. Scirpusin B significantly depressed this increase 15 and $30 \mathrm{~min}$ after being given.

It has been said that disturbing absorption of glucose derived from meals in the gastrointestinal tract is helpful to remedy mild cases of non-insulin-dependent (type 2) diabetes mellitus that cannot be controlled by either diet or exercise. Suppression of abnormal increase of blood glucose level after meals is considered effective as preventive measure against type 2 diabetes mellitus, as well as against cardiac and vascular diseases. Folk medicinal use of essential oils of Callistemon rigidus has been recorded against cough, bronchitis, and respiratory infections in Europe. ${ }^{6}$ Our studies 


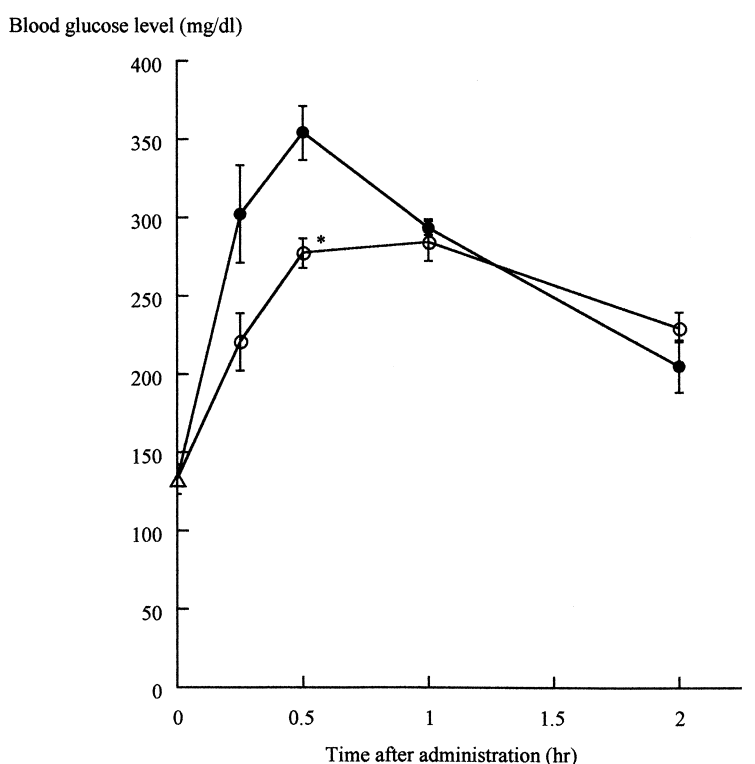

Fig. 2. Variation of Blood Glucose Level in Glycogen-Loaded Mouse Plasma after Oral Administration of Scirpusin B

$\mathrm{O}$, scirpusin B $(400 \mathrm{mg} / \mathrm{kg}$, p.o. $)$ and glycogen $(1500 \mathrm{mg} / \mathrm{kg}$, p.o. $) ; \bullet$, glycogen alone $(1500 \mathrm{mg} / \mathrm{kg}$, p.o. $) ; \triangle$, without glycogen and scirpusin B. All values represent the mean of 3 mice/group. Vertical lines show the standard error of the mean. * Significantly different from control, $p<0.05$.

suggest a new biological activity of this plant and its constituent scirpusin $\mathrm{B}$, namely, they may mildly inhibit $\alpha$-amylase activity in the gastrointestinal tract, and consequently this may be expected to contribute clinically to gentle improvement of postprandial hyperglycemia in diabetic patients.

\section{REFERENCES}

1) Kobayashi K., Saito Y., Nakazawa I., Yoshizaki F., Biol. Pharm. Bull., 23, $1250-1253$ (2000).

2) Kobayashi K., Baba E., Fushiya S., Takano F., Batkhuu J., Dash T., Sanchir C., Yoshizaki F., Biol. Phram. Bull., 26, 1045-1048 (2003).

3) Caraway W. T., Am. J. Clin. Path., 32, 97-99 (1959).

4) Sasaki M., Rinsho Byori, 12, $434-437$ (1964).

5) Ogunwande I. A., Olawore N. O., Kasali A. A., Ekundayo O., Konig W. A., J. Essential Oil Bearing Plants, 5, 55-59 (2002).

6) Jirovetz L., Fleischhacker W., Buchbauer G., Ngassoum M. B., Scientia Pharmaceutica, 65, 315-319 (1997).

7) Siqueira N. C. S., Silva G. A. A. B., Alice C. B., Thiesen F. V., Rev Bras. Farm., 68, 78-81 (1987).

8) Hashim F. H., El-Shamy A. M., Shehata A. H., Bull. Facul. Pharm (Cairo Univ.), 19, 131-138 (1982).

9) Takemoto T., Yahagi N., Yakugaku Zasshi, 75, 473 - 474 (1955).

10) Mannila E., Talvitie A., Phytochemistry, 31, 3288-3289 (1992).

11) Bavaresco L., Fregoni M., Trevisan M., Mattivi F., Vrhovsek U., Falchetti R., Vitis, 41, 133-136 (2002).

12) Kashiwada Y., Nonaka G., Nishioka I., Chem. Pharm. Bull., 32, 3501-3517 (1984).

13) Nakajima K., Taguchi H., Endo T., Yoshioka I., Chem. Pharm. Bull., 26, 3050-3057 (1978).

14) Kulesh N. I., Maksimov O. B., Fedoreev S. A., Denisenko V. A., Glasunov V. P., Pokushalova T. V., Glebko L. I., Chem. Nat. Comp., 35, 575-579 (1999).

15) Yokose K., Ogawa K., Suzuki Y., Umeda I., Suhara Y., J. Antibiot., 36, 1166-1175 (1983).

16) Hosoyama H., Sugimoto A., Suzuki Y., Sakane I., Kakuda T., Yakugaku Zasshi, 123, 599-605 (2003).

17) Fukuda T., Ito H., Yoshida T., Abstracts of papers, the 50th Annual Meeting of the Japanese Society of Pharmacognosy, Tokyo, September 2003, p. 228.

18) Gebbia N., Bavaresco L., Fregoni M., Civardi S., Crosta L., Ferrari F., Grippi F., Tolomeo M., Trevisan M., Vignevini, 30, 87-94 (2003).

19) Ko S. K., Lee C. R., Lee H. S., Kim H., Baek K. H., Tokuoka K., Chung S. H., Saengyak Hakhoechi, 34, 25-27 (2003).

20) Schmeda-Hirschmann G., Gutierrez M. I., Loyola J. I., Zuniga J., Phytother. Res., 10, 683-685 (1996). 